\title{
Evaluation of Copper Acute Toxicity in Common Carp (Catla Catla L.)
}

\author{
Gutha Rajasekar $^{1}$, Yarrappagaari Suresh ${ }^{2}$, Thopireddy Lavanya ${ }^{3}$, Saddala Rajeswara Reddy $^{4}$ \\ 1, 2, 4 Division of Animal Biotechnology, Dept of Biotechnology, School of Herbal studies and naturo Sciences, Dravidian University, \\ Kuppam-517426,A.P, India
}

${ }^{3}$ Dept of Zoology, Government Degree College, Kuppam-517426,A.P, India

\begin{abstract}
The main aim of the toxicological evaluations are estimating the maximum dose that may be tolerated by animals throughout their life time without showing any adverse effect. The lethality of a toxicant to a particular organism is expressed in terms of mortality and time. The $\mathrm{LC}_{50}$ is the concentration of a chemical which kill $50 \%$ in a group of experimental aquatic animals with in a given time period. Thus, the toxicity of a copperis evaluated in this study and identified 260ug/l copper kills $50 \%$ of fish Catla catla. This is highly helpful in the determination of safe level (or) tolerable level of copper to the aquatic environment.
\end{abstract}

Keywords: Copper, Toxicity, Catla catla, Lethality

\section{Introduction}

Aquatic toxicity test are performed so as to evaluate the response of aquatic organisms and to identify or measure the presence or effect of one or more substances, wastes or environmental factors, alone or in combination [1].Acute toxicity is a major interest of aquatic toxicology for evaluating the chemical toxicity test for measuring the harmful threats of chemical contamination to aquatic organisms [2]. In general, the biological effects of toxicants can be observed at molecular, cellular, tissue, organismic, family and population levels by behavioral, physiological and pathological means [3].

Toxicity tests are important in assessing the response of organisms exposed to pollutants compared to a control, so bioassay tests have been used to evaluate the toxicity levels of compounds for aquatic organisms. There have been many types of toxicity assays employing to characterize the potential ecotoxicological effects of all types of toxicants and validity of these tests are standardized and established by ISO or OECD [4].The biological response induced by toxicants are different among living organisms and it depends on their sensitivity to toxicants. The practice of an array of bioassays involving many bio indicator species at different trophic levels is a highly effective and vital method for analysing environmental threats to the aquatic ecosystem.

Many test organisms have been used as bio indicators to assess of ecotoxicity of anthropogenic compounds on aquatic ecosystems [5]. However, fish are generally used for evaluating the effects of environmental pollution on aquatic ecosystem in the aquatic environment [6]. Fish and other aquatic fauna are continuously exposed to chemicals in polluted and waste waters. Fishes have been observed to be reliable indicators of pollution in aquatic ecosystems because they occupy different trophic levels and are of different sizes and ages [7]. Also, it is vital to study the toxic effects of chemicals on fish because they form an important link in food chain and their contamination in aquatic bodies imbalances the aquatic system by pollution [8]. Like mammals, the fish develop the same biochemical pathways in response to the toxic effects of endogenous and exogenous agents [9].

Heavy metals when reaches water bodies, decline the life sustaining conditions of water and affects both flora and fauna [10]. If the duration of contact to heavy metals are prolonged in the aqueous environment, the low levels of heavy metals become lethal or sub lethal to aquatic organisms [11]. The wide spread usage of metals finally polluting the aquatic environment and affecting the aquatic fauna especially fishes, which represent the major economy of the country and valuable source of protein. Thus, the complexities of the interaction of the metals with the biological systems of the fishes gained greater attention of scientists. Knowledge from different toxicity assays can be helpful in the management of pollution, Prediction of environmental damage and regulation of waste discharge.

Thus, an attempt was made in the current study to evaluate the acute toxicity of copper to the freshwater teleost, Catla catla to assess potential risk of the copper. The present study is commenced with the determination of 96 hours LC50 for copper to freshwater fish, Catla catla. The toxicity of copper was determined to assess the $\mathrm{LC}_{50}$ and sub-acute doses. Although literature showed the lethality of copper to other fish species, toxicity responses varies from species to species evidencing differences in their values. Therefore, it is pertinent to evaluate the susceptibility of the Catla catla to copper.

\section{Material \& Methods}

\section{Experimental design}

The carp fish (Catla catla) used for this study were procured from local ponds. Fish were placed in a $50 \mathrm{~L}$ glass aquarium with aerated and filtered dechlorinated water. Fish were fed on commercial diet during experiment period and were acclimated to the laboratory conditions for 4 weeks under natural photoperiod prior to experiment. During acclimatization period, the water (three fourth of the water) was changed daily to maintain healthy environment and the 


\section{International Journal of Science and Research (IJSR) \\ ISSN (Online): 2319-7064}

Index Copernicus Value (2015): 78.96 | Impact Factor (2015): 6.391

physicochemical characteristics of tap water such as temperature, $\mathrm{pH}$, dissolved oxygen, total alkalinity and total hardness. No attempt was made to separate the sexes and the fish were starved for $24 \mathrm{~h}$ prior to experimentation, which gave sufficient time for the gut to be emptied.

\section{Toxicity evaluation}

Then, acclimatised fish of equal size $(12 \mathrm{~cm})$ and an average weight of $26 \mathrm{~g}$ were used for experimentation and the renewal technique was followed [12]. Next, the stock solution of copper was prepared by dissolving appropriate amounts of copper sulfate pentahydrate. After acclimatization to laboratory, the healthy fish were randomly divided into ten groups (10 fish per group). After fish was exposed to different concentration of copper, the mortality of the fish were checked every 24, 48, 72 and $96 \mathrm{~h}$ exposure period. The data were analysed by Finney, 1971 and lethal and sub-lethal concentration levels were determined.

\section{Results}

In this study, mortality of fish were observed after copper exposure. To assess the lethality of copper, concentrations ranges $170 \mu \mathrm{g} / \mathrm{l}$ to $340 \mu \mathrm{g} / \mathrm{l}$ of copper were used and found concentration of copper at which $50 \%$ mortality $\left(\mathrm{LD}_{50}\right)$ could be obtained at $98 \mathrm{hrs}$ exposure. The doses of copper about $170 \mu \mathrm{g} / \mathrm{l}$ of copper exposure did not shown any mortality but $10 \%$ mortality at $200 \mu \mathrm{g} / \mathrm{l}$ of copper, $30 \%$ mortality at $230 \mu \mathrm{g} / \mathrm{l}$ of copper, $50 \%$ mortality at $260 \mu \mathrm{g} / \mathrm{l}$ of copper, $70 \%$ mortality at $290 \mu \mathrm{g} / 1$ of copper, $90 \%$ mortality at $310 \mathrm{mg}$, and $100 \%$ mortality at $330 \mu \mathrm{g} / \mathrm{l}$ of copper exposure was observed. It was found that the mortality increased as the dose or concentration increases. The obtained results like mortality number, concentration of copper, per cent mortality and probit kill shown in Table 1. The per cent mortality against different log concentrations of copper shown a typical sigmoid curve (Figs. 1). The $\mathrm{LD}_{50}$ value obtained from the sigmoid curve was observed to be $260 \mu \mathrm{g} / \mathrm{l}$ for copper. The probit mortality was plotted against log concentrations of the copper, a straight line was obtained (Figs. 2). The $\mathrm{LD}_{50}$ value obtained from this straight line was also found to be $260 \mu \mathrm{g} / \mathrm{l}$ graphs for copper (Table2)

Table 1: Mortality of Catla catla in different concentration of copper at 96 hours of exposure period (Mortality was expressed both in per cent and probit kill)

\begin{tabular}{|c|c|c|c|c|c|c|}
\hline Sl. & Concentration & $\log$ & No of ar & imals & Percent & Probit \\
\hline No & $(\mu \mathrm{g} / \mathrm{L})$ & Concentration & Exposed & Dead & Mortality & Mortlity \\
\hline 1 & $170 \mu \mathrm{g}$ & 2.2304 & 10 & - & - & - \\
\hline 2 & $200 \mu \mathrm{g}$ & 2.3010 & 10 & 1 & $10 \%$ & 3.72 \\
\hline 3 & $230 \mu \mathrm{g}$ & 2.3617 & 10 & 3 & $30 \%$ & 4.48 \\
\hline 4 & $260 \mu \mathrm{g}$ & 2.4149 & 10 & 5 & $50 \%$ & 5.00 \\
\hline 5 & $\mu \mathrm{g}$ & 2.4623 & 10 & 7 & $70 \%$ & 5.52 \\
\hline 6 & $310 \mu \mathrm{g}$ & 2.4913 & 10 & 9 & $90 \%$ & 6.28 \\
\hline 7 & $340 \mu \mathrm{g}$ & 2.5314 & 10 & 10 & $100 \%$ & 8.09 \\
\hline
\end{tabular}

Table 2: Comparison of LC50 value of copper to Catla catla after 96 hours of exposure calculated from different methods

\begin{tabular}{|c|c|c|}
\hline S1. No. & Name of the Method & LC50 value $(\mu \mathrm{g} / \mathrm{l})$ \\
\hline 1 & Percent mortality (Sigmoid curve) & $260 \mu \mathrm{g} / 1$ \\
\hline 2 & Probit mortality (Linear curve) & $260 \mu \mathrm{g} / 1$ \\
\hline
\end{tabular}

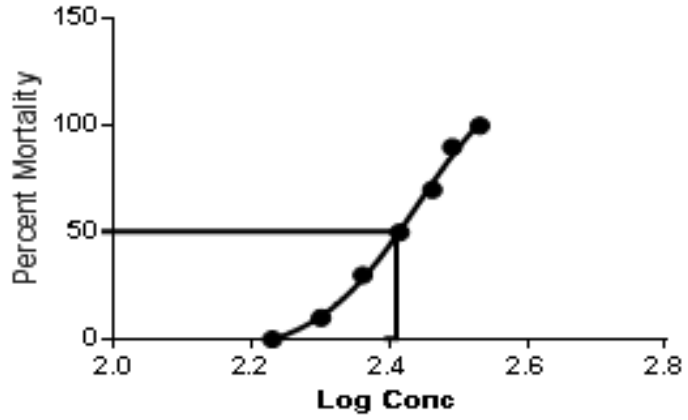

Figure 1: Toxicity evaluation of copper to freshwater fish, Catla catla. The graph showing sigmoid curve between percent mortality of fish against log concentration.

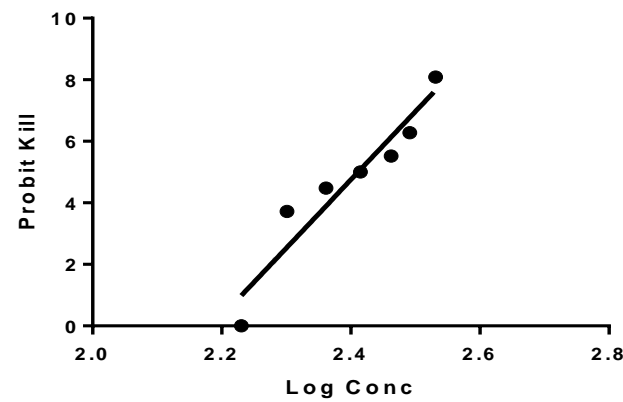

Figure 2: Toxicity evaluation of copper to freshwater fish, Catla catla. The graph showing linear curve between probit mortality of fish against log concentration.

\section{Discussion and Conclusion}

Toxicology and ecotoxicology evaluation depends on acute toxicity testing for identification and classification of environmental hazards [13]. Therefore, many studies have been conducted to understand the effects of toxicants on the physiology and mortality of many organisms [14]. Aquatic toxicology aimed at determination of pollutants and characterization of adverse effects caused on the aquatic environment; moreover, this field of study may include information on effects caused to humans in and around these aquatic environments. Aquatic toxicity of pollutants often can be very useful in identifying the acute damage to aquatic fauna as water receives toxic wastes discharges [15].

Acute toxicity is referred as the harmful effects after a short time of exposure of a toxicant. It is helpful to understand the quantity below which it may be considered safe for a particular toxicant in the environment [16]. Further, these toxicity studies are the very useful in evaluating the water quality parameters required for fish. In aquatic toxicology, mortality is the important factor since it is easy to evaluate and has obvious biological and ecological significance.

The toxicity of heavy metals has been evaluated in different fish species (Table.3) In the present study, toxicity evaluation of heavy metal copper was conducted on the c.catla and the LC50 values for 96h was observed to be $260 \mu \mathrm{g} / 1$ (Table 2). It has also been studied the toxicity of copper to other fishes by various toxicologists (Table4). It was found that that LC50 values of copper for razorback sucker, bull trout, greenthroat darter, fathered minnow and fantail darter range between $260 \mu \mathrm{g} / 1$ and $330 \mu \mathrm{g} / 1$. The 


\section{International Journal of Science and Research (IJSR) \\ ISSN (Online): 2319-7064}

Index Copernicus Value (2015): 78.96 | Impact Factor (2015): 6.391

acute toxicity values strongly suggests negative effects on survival as copper concentration increased. The cause for mortality is heavy metal toxicity and it depends primarily on time and concentration combinations

Table 3: Data depicting the acute toxicity of different metals on fresh water fish species

\begin{tabular}{|c|c|c|c|c|c|}
\hline $\begin{array}{c}\text { S1. } \\
\text { No }\end{array}$ & $\begin{array}{c}\text { Test } \\
\text { Species }\end{array}$ & $\begin{array}{c}\text { Exposure } \\
\text { Acute/ } \\
\text { chronic }\end{array}$ & Metal type & $\begin{array}{c}\text { Concentration } \\
(\mu \mathrm{g} / \mathrm{l})\end{array}$ & Reference \\
\hline 1 & $\begin{array}{c}\text { Channa } \\
\text { punctatus } \\
\text { (Bloch) }\end{array}$ & Acute & $\mathrm{HgCl} 2$ & $1.21 \mu \mathrm{g}$ & $\begin{array}{c}\text { Sanjay } \\
\text { Pandey,et al. } \\
2004\end{array}$ \\
\hline 2 & $\begin{array}{c}\text { Labeo } \\
\text { rohita }\end{array}$ & Acute & Chromium & $39.40 \mathrm{mg} / \mathrm{l}$ & $\begin{array}{c}\text { S. S. } \\
\text { Vutukuru, } \\
2005\end{array}$ \\
\hline 3 & Catla catld & Acute & Chromium & $100 \mathrm{mg} / 1$ & $\begin{array}{c}\text { Vincent, et } \\
\text { al.1996 }\end{array}$ \\
\hline 4 & $\begin{array}{c}\text { Cyprinus } \\
\text { carpio }\end{array}$ & Acute & $\mathrm{Cu}$ & $1 / 1111.0 \mathrm{ug} .0$ & $\begin{array}{c}\text { M. K. Alam } \\
\text { et al. 1991 }\end{array}$ \\
\hline 5 & $\begin{array}{c}\text { Capoeta } \\
\text { fusca, }\end{array}$ & Acute & $\mathrm{Zinc}$ & $13.7 \mathrm{mg} / 1$ & $\begin{array}{c}\text { Mohammad } \\
\text { ebrahimpour }\end{array}$ \\
\hline 6 & $\begin{array}{c}\text { Cyprinus } \\
\text { carpio }\end{array}$ & Acute & $\mathrm{Fe}$ & $3.70 \mathrm{~g} / \mathrm{l}$ & $\begin{array}{c}\text { M. K. } \\
\text { Alam*t al. } \\
1991\end{array}$ \\
\hline
\end{tabular}

Table 4: Data depicting the acute toxicity of copper to different fresh water fishes

\begin{tabular}{|c|c|c|c|c|}
\hline $\begin{array}{c}\text { Sl. } \\
\text { No. }\end{array}$ & Test Species & $\begin{array}{c}\text { Exposure } \\
\text { Acutel } \\
\text { chronic }\end{array}$ & $\begin{array}{c}\text { Concentration } \\
(\mu g / l)\end{array}$ & Reference \\
\hline 1 & $\begin{array}{c}\text { Cutthroat trout } \\
\text { (oncorhynchus } \\
\text { clarkii) }\end{array}$ & Acute & 398.91 & $\begin{array}{c}\text { Chakoumakos } \\
\text { et al. 1979 }\end{array}$ \\
\hline 2 & $\begin{array}{c}\text { Pink salmon or } \\
\text { humpback } \\
\text { salmon } \\
\text { (Oncorhynchus } \\
\text { gorbuscha) }\end{array}$ & Acute & 143 & $\begin{array}{c}\text { Servizi and } \\
\text { Martens 1978 }\end{array}$ \\
\hline 3 & $\begin{array}{c}\text { Coho salmon } \\
\text { (oncorhynchus } \\
\text { kisutch }\end{array}$ & Acute & 164 & Buckley 1983 \\
\hline 4 & $\begin{array}{c}\text { Rainbow trout } \\
\text { (Oncorhynchus } \\
\text { mykiss) }\end{array}$ & Acute & 110 & Dwyer et al. \\
1995
\end{tabular}

\section{References}

[1] Muniyan, M. and K. Veeraraghavan, Acute toxicity of ethofenprox to the freshwater fish, Oreochromis mossambicus(Peters). Journal of Environmental Biology, 1999. 20(2): p. 153-155.

[2] Patil, G. and R. Dhande, EFFECT OF MERCURY AND COPPER ON OVARIAN RECRUDESCENCE IN THE FRESHWATER FISH, CHANNA PUNCTATUS. JOURNAL OF ECOTOXICOLOGY AND ENVIRONMENTAL MONITORING, 2001. 11(2): p. 83-90.

[3] Postma, J., et al., Confounding factors in bioassays with freshwater and marine organisms. Ecotoxicology and Environmental Safety, 2002. 53(2): p. 226-237.

[4] Nunes, B., et al., Behaviour and biomarkers of oxidative stress in Gambusia holbrooki after acute exposure to widely used pharmaceuticals and a detergent. Ecotoxicology and environmental safety, 2008. 71(2): p. 341-354.

[5] Gernhöfer, M., et al., Ultrastructural biomarkers as tools to characterize the health status of fish in contaminated streams. Journal of Aquatic Ecosystem Stress and Recovery, 2001. 8(3-4): p. 241-260.

[6] Burger, J., et al., Metal levels in fish from the Savannah River: potential hazards to fish and other receptors. Environmental research, 2002. 89(1): p. 85-97.

[7] Oruç, E.Ö. and D. Usta, Evaluation of oxidative stress responses and neurotoxicity potential of diazinon in different tissues of Cyprinus carpio. Environmental Toxicology and Pharmacology, 2007. 23(1): p. 48-55.

[8] Lackner, R., "Oxidative stress" in fish by environmental pollutants, in Fish ecotoxicology. 1998, Springer. p. 203-224.

[9] Verma, R., et al., Heavy metal toxicity to fresh water prawn, Macrobrachium dayanum (CrustaceaDecapoda). Aquaculture, 2005. 6(1): p. 57-62.

[10]Eisler, R. and G.R. Gardner, Acute toxicology to an estuarine teleost of mixtures of cadmium, copper and zinc salts. Journal of Fish Biology, 1973. 5(2): p. 131142.

[11] Castaño, A., et al., The use of fish cells in ecotoxicology. The report and recommendations of ECVAM Workshop 47. Alternatives to laboratory animals: ATLA, 2003. 31(3): p. 317.

[12] Weber, C.I., Methods for measuring the acute toxicity of effluents and receiving waters to freshwater and marine organisms. 1991: Environmental Monitoring Systems Laboratory, Office of Research and Development, US Environmental Protection Agency.

[13] Scott, G.R. and K.A. Sloman, The effects of environmental pollutants on complex fish behaviour: integrating behavioural and physiological indicators of toxicity. Aquatic toxicology, 2004. 68(4): p. 369-392.

[14] Vutukuru, S., Acute effects of hexavalent chromium on survival, oxygen consumption, hematological parameters and some biochemical profiles of the Indian major carp, Labeo rohita. International Journal of Environmental Research and Public Health, 2005. 2(3): p. $456-462$.

[15] Sprague, J., Measurement of pollutant toxicity to fishIII: Sublethal effects and "safe" concentrations. Water Research, 1971. 5(6): p. 245-266. 


\section{International Journal of Science and Research (IJSR) \\ ISSN (Online): 2319-7064}

Index Copernicus Value (2015): 78.96 | Impact Factor (2015): 6.391

[16] Ay, Ö., et al., Copper and lead accumulation in tissues of a freshwater fish Tilapia zillii and its effects on the branchial Na, K-ATPase activity. Bulletin of environmental contamination and toxicology, 1999. 62(2): p. 160-168.

[17] Ribeiro, C.O., et al., Bioaccumulation and the effects of organochlorine pesticides, $P A H$ and heavy metals in the Eel (Anguilla anguilla) at the Camargue Nature Reserve, France. Aquatic Toxicology, 2005. 74(1): p. 53-69. 